Conference and exhibition on the evening of March 29 and it also received considerable attention from the Press. On Friday evening, March 29, Mr. R. A. Watson Watt delivered a public lecture, which was attended by about 350 people, on "Cathode Ray Tubes in Industry". The lecture was given in the Great Hall of the College of Technology. It is hoped, in these ways, to bring to the notice of all, the great possibilities of existing inventions and scientific knowledge of a physical character, and the important part which these play in everyday life.

The social events included a Conference dinner in the College of Technology, at which Sir Henry G. Lyons, the president of the Institute, presided, and the guests included the Lord Mayor and the Lady Mayoress of Manchester, and a number of other distinguished persons.

The great success of this Conference renders it likely that similar conferences will be held from time to time in the future. Apart from the value of the information gained from the various lectures and discussions, as well as from the exhibition and the visits, the contacts made between physicists and those concerned with the technical developments of industry cannot but prove a fruitful source of lasting mutual benefit.

Herbert R. Lang.

\section{University Education}

T HE inaugural address of the president of the Royal Statistical Society, Prof. M. Greenwood, delivered on November 20, 1934, contained many points of interest concerning the past history and probable future of the universities of Great Britain (J. Roy. Statistical Soc., 98, 1-37, 1935).

By consideration of birth-rates, there should be a decline in numbers at the universities in $1935-36$, a recovery in 1938-9, and then, unless there is a change of policy, a steady decline. The present entrance requirements are not unduly severe; in fact, if we adopt the view of some university teachers, that failure to obtain first or second class honours shows unsuitability for university training, more than fifty per cent of the unassisted students should have been. excluded, and also 10-25 per cent of those assisted by scholarships and similar benefactions. Dr. A. Flexner, who considers that a university suitable for the present and future of the world should be concerned with the conservation and interpretation of knowledge and ideas, the search for truth, and the training of students, concedes that Oxford and Cambridge have touched the fringe of these ideals, but he finds it impossible to give even this faint praise to any other English university, least of all to London. Mr. H. G. Wells doubts whether the universities and the conceptions of education they embody are destined to any very prolonged predominance over the intellectual processes of mankind, and considers the ordinary arts course in our older universities to be "merely a wasteful prolongation of puerility". Even Dr. H. Rashdall, who cannot be accused of prejudice against the ancient universities, observes that "Universities have often had the effect of prolonging and stereotyping ideas and modes of thought for a century or more after the rest of the world has given them up".

However, Prof. Greonwood considers that Dr. Flexner's ideals are too narrow, and are capable of realisation only in small and cloistered communities like Oxford and Cambridge. For large cities such as London, he considers that the loss of intimacy may be compensated by a gain in continuity, and that requirements should be made less rigid, so as to have no chasms between matriculated and non-matricu. lated students, or between graduates and nongraduates. In the past, one supported education largely on the ground that an educated nation would be better fitted to secure advantages in the international struggle for markets. But there has been a fundamental change in economic conditions. Now that productive man-power is in excess of demand, and millions of man-hours are running to waste, higher education should be considered, not for the material or social advantage it confers, but as a path to happiness.

In the discussion that followed the address, Mr. Udny Yule deprecated some of the sterner judgments on the University of London, and suggested that it differs from the older universities in degree rather than in kind. The research worker is the evolutionary successor of the hunter and is not a being apart, stripped of emotion, an intellectual machine. On this view we can understand his psychology, his blunders, his emotions. In fact, it is impossible to draw a sharp line between the investigations of a detective and those of the best type of fellow of the Royal Society. Even a poor piece of investigation may have taught much to the investigator himself, and have given him many happy hours.

\section{University and Educational Intelligence}

London.-Dr. John Gray, since 1934 director of pathology and Lyle research scholar at Queen Mary's Hospital for the East End, has been appointed reader in morbid anatomy at the British Postgraduate Medical School, as from April 1.

On his retirement from the professorship of surgery at St. Bartholomew's Hospital Medical College at the end of the present session, the title of emeritus professor in surgery in the University will be conferred on Prof. G. E. Gask.

The Senate has approved a proposal to hold the School Examinations (General School and Higher School) overseas in and after 1936.

Str. Andrews.-The Senatus Academicus has resolved to confer honorary degrees on the following, among others : LL.D., the Right Hon. Lord Alness; Andrew Bennett, secretary of the University since 1903, and secretary of the Scottish Universities Entrance Board; Prof. C. H. Browning, Gardiner professor of bacteriology in the University of Glasgow ; Prof. A. H. Gibson, Beyer professor of engineering and director of the Whitworth Laboratories in the Victoria University of Manchester ; Sir John Boyd Orr, director of the Rowett Institute, Aberdeen.

The Fifth Quinquennial Congress of Universities of the Empire, organised by the Universities Bureau of the British Empire, will be held at Cambridge on July 13-17, 1936.

UNIVERSTrY education in the United States is breaking free from the traditional system of semesterhour credits with compulsory class attendance and teaching by textbooks. More than a hundred universities and colleges have, says Dr. McNeely of 
the Federal Office of Education in a paper contributed to School and Society, adopted in varying degrees devices for substituting voluntary learning on the part of the student for external compulsion. Among the leaders are the University of Chicago, Harvard, Cornell and Buffalo Universities and Swarthmore and Goucher Colleges.

OF German professors expatriated owing to Nazi intolerance, thirty-four have, it appears, migrated to the United States, and sixteen of them have been assigned to various universities by an "Emergency Committee in Aid of Displaced German Scholars". The remainder have combined in New York to form under the leadership of Dr. Alvin Johnson, director of the New School for Social Research, an association known as "The University in Exile". An article in School and Society of February 23 announces the appointment of a permanent board of trustees for the association. The association aims at perpetuating "the free German culture, which it had become traditional that post-graduate students from America and all over the world should seek, as a complement to the facilities of their own lands" : the words are quoted from a statement by the chairman of the board, Mr. I. A. Hirschmann.

The Royal Institute of Science, Bombay, which began teaching work in 1920, has recently issued a report (Bombay : Government Central Press, pp. 74, gratis) covering the period 1926-34. The declared policy of the Institute has been : (1) to interest the public by popular lectures and demonstrations, (2) to qualify undergraduates for scientific investigation, (3) to provide the means for carrying out original work, to guide beginners in research and to cooperate, on occasion, with other scientific institutions and assist industry by investigating industrial problems. The staff comprises, in addition to the principal, Dr. T. S. Wheeler, sometime senior research chemist with Imperial Chemical Industries, Ltd., eighteen professors, lecturers and demonstrators in chemistry, physics, botany, zoology and mathematics. The students, excluding courses in physics for firstyear arts students, number about 300 and the annual cost of their education is Rupees 608 per student. There has been in the past ten years a steady increase from 26 (being 15 per cent of all full-time students) to 91 (31 per cent) in the number of post-graduate students. Progress in developing the Institute's research activities is further indicated in a list of 128 papers published and abstracts of 101 researches in progress. Both staff and students are, the report says, keen on their work, and the library and laboratories are open until late in the evening, even during vacations. A frontispiece to the report gives a view of the impressive façade, 400 yards long, of the Institute building, a wing of which was handed over in November 1933 to the University of Bombay to house the new University Department of Chemical Technology.

\section{Science News a Century Ago}

\section{Monument to Telford}

In The Times for Tuesday, April 7, 1835, it was stated that "At a general meeting of the Dundee Harbour Trustees on Wednesday last, it was moved by Mr. David Baxter that the harbour trustees do subscribe 10 guineas to the general subscription in
London for a monument to the memory of Thomas Telford, Esq., Engineer, to be erected in Westminster Abbey, in consideration of the valuable services rendered by that distinguished engineer to the harbour of Dundee, first, in giving the very excellent plan for the construction of the first wet dock now called King William's-dock; 2nd, in the valuable professional and practical advice which he gave for carrying the work into effect; $3 \mathrm{rd}$, in procuring from Government, by the Exchequer Loan Commissioners, at a time when the erection of the harbour was considered to be a work of speculation, a loan of the sum of $£ 30,000$ (nearly all this has since been repaid); and lastly for giving his able assistance in carrying the perpetual bill of 1830 through Parliament, which has placed the harbour establishment in a situation that has made it at once the cheapest and one of the most improved harbours in this kingdom".

\section{Lardner on Halley's Comet}

On April 10, 1835, Lardner gave the first of two lectures on Halley's comet at the Royal Institution. In the course of his lecture, he said that in 1757 Lalande proposed to Clairaut the calculation of Halley's comet, which was expected to return shortly. They were assisted by a French lady, the wife of a chronometer maker. The calculation was enormous, because the orbit must be divided into degrees, and each degree required as great a calculation as the whole orbit. They tell us, he said, that they were employed from morning to night, not excepting meal hours, incessantly for six months in this computation. Clairaut was so nervous that he hurried his calcula. tions before the Institute. "Although Clairaut was not quite enrrect to the day, the only wonder was, that he should have been so accurate, for as he said, when a body traverses a space of $1,500,000,000$ miles beyond our sphere of observation, how do we know but that some other planet may act upon it, and influence its course. In 25 years the planet Herschel was discovered, which it was proved, did actually operate in producing the effect which Clairaut had surmised".

\section{Railways in France}

According to the Mechanics' Magazine for April 11, 1835, the French Minister, M. Thiers, had just presented to the Chamber of Deputies "a project of law relating to railroads. He announced that the Government engineers had fixed upon three principal lines for railroads-one from Paris to Havre, via St. Denis, Pontoise, and Gisors, with branch lines to Rouen and Dieppe; a second from Paris to Lyons and Marseilles; and a third from Paris to Lille, Bourdeaux and Strasbourg. Surveys have it appears been made, and plans drawn out for these three several lines; but one only, that from Paris to Havre, is recommended to be at first undertaken. It is proposed to throw open the work to public competition, and to entrust it to any company who will offer the best conditions, and sufficient securities". A fortnight later the Mechanics' Magazine said that there were in operation in France railroads from St. Etienne to the Loire (thirteen miles), St. Etienne to Lyons (thirty-seven miles) and Andrezieux to Roane (forty-two miles), while two other lines under construction ran from Alais to Beaucaire (fortythree miles) and from Epiney to the Canal of Burgundy (seventeen miles). 